green; tail-feathers dark bluish green, glossy bronzy green on the outer aspect ; crown of head dingy brown with a very slight bronzy gloss, the forehead, lores, and base of cheeks ashy grey; the earcoverts, remainder of cheeks, throat, and fore neck dusky ashy, with a slight vinaceous tinge which is a little more pronounced on the breast and abdomen; the sides of the body, flanks, and thighs dark slaty grey with a greenish gloss; under tail-coverts chestnut-brown; under wing-coverts and axillaries dark slaty grey ; quills light ashy underneath. Total length 16.5 inches, culmen from irontal plumes 0.85 , wing $10 \cdot 3$, tail $6 \cdot 8$, tarsus $1 \cdot 25$.

Ardea Jugularis, Forster; Schlegel, Mus. Pays-Bas, Ardeæ, p. 25 .

A female in entirely white plumage. The legs are yellow, more dusky on the tarsus, which has a good deal of black.

Sula Piscatrix (L.) ; Schlegel, Mus. Pays-Bas, Pelecani, p. 40. An adult female in full plumage.

Fregata aquila (L.) ; Schlegel, t. c. p. 2.

An adult bird. An interesting note on the habits of the bird in the neighbourhood of Java is given, from the notes of the Vicomte de Bocarmé, in Schlegel's 'Catalogue' (l.c.).

\title{
III. REPTILES.
}

\section{By G. A. Boulenger.}

\section{Gymnodactylus marmoratus, Kuhl.}

\section{Lygosoma nativitatis, sp. n.}

Section Emoa. Habit lacertiform; the distance between the end of the snout and the fore limb is contained once and a half in the distance between axilla and groin. Snout long, obtuse. Lower eyelid with an undivided transparent disk. Nostril pierced between a nasal, a postnasal, and a supranasal; frontonasal broader than long, forming a suture with the rostral and with the frontal; latter shield nearly as long as the frontoparietal, in contact with the first and second supraoculars; four supraoculars; eight supraciliaries; frontoparietals united into a single large shield; a small interparietal, behind which the parietals form a suture; a pair of nuchals and a pair of temporals border the parietals; five labials anterior to the large subocular. Ear-opening oval, a little larger than the transparent palpebral disk, with three or four very small lobules on its anterior border. Thirty-four scales round the middle of the body, all smooth, lateral a little smaller than dorsal and ventral. No enlarged pıæanals. The hind limb reaches the elbow. Digits moderately elongate, a little flattened at the base, compressed at the 
end; subdigital lamellæ smooth, thirty-two under the fourth toe. Brown above, strongly iridescent, with small golden and blackish spots, most numerous on the sides and limbs; lower surfaces white.

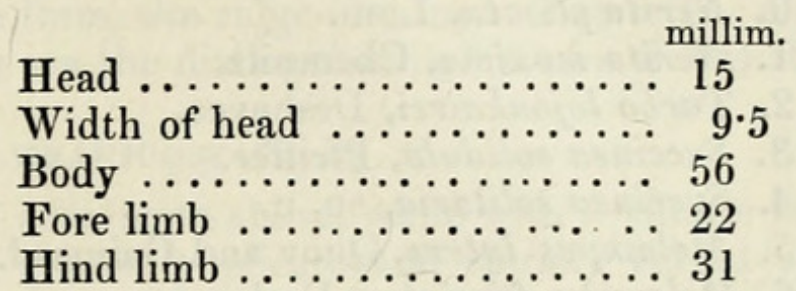

A single female specimen, without tail.

3. TyphLOPS EXoceti, sp. $n$.

Body much elongate, of subequal diameter throughout. Snout depressed, rounded. Nasal semidivided, the suture in contact with the second labial; a præocular, of about the same size as the ocular, which rests on the third and fourth labials; eye very distinct, under the ocular; the so-called rostral rounded and narrowing posteriorly, the length of its upper part about equal to its width. Twenty scales round the middle of the body. Tail twice as long as broad at the base, ending in a spine. Pale brownish, each scale with a brown spot; these spots largest and darkest on the dorsal surface, where they form longitudinal lines.

Two specimens, of which the dimensions are as follows :-

$a$. Total length 350 millim., diameter of body 6 , length of tail 8 . tail 6 .

$b$. Total length 230 millim., diameter of body $3 \cdot 5$, length of

\section{MOLLUSCA.}

\section{Ву Е. А. Змітн.}

Of the sixteen species of shells obtained at Christmas Island, fourteen belong to well-known forms, but two, a Succinea and a Littorina, appear to be new. No locality has been previously assigned to Nerita maxima, and Littorina picta has hitherto been known from the Sandwich Islands only. All or most of the marine forms occur both in the Malay Archipelago and Polynesia. The Melampi have an equally wide distribution; and the species of Succinea, although considered distinct, like most others of the genus, bears a great resemblance to those from other parts of the world.

The following is a list of the species :-

*1. Terebra crenulata, Linn.

2. Columbella (Pusiostoma) mendicaria, Lamarck.

3. Sistrum ricinus, Linn. (var. albolabris).

4. Mitra virgata, Reeve.

5. Ranella cruentata, Sowerby.

*6. Triton chlorostoma, Lamarck.

* These species are all inhabited by Puguri. 


\section{$2 \mathrm{BHL}$ Biodiversity Heritage Library}

Boulenger, George-Albert. 1887. "III. REPTILES." Proceedings of the Zoological Society of London 1887, 516-517.

https://doi.org/10.1111/j.1096-3642.1887.tb03001.x.

View This Item Online: https://www.biodiversitylibrary.org/item/99199

DOI: https://doi.org/10.1111/j.1096-3642.1887.tb03001.x

Permalink: https://www.biodiversitylibrary.org/partpdf/73024

\section{Holding Institution}

Natural History Museum Library, London

\section{Sponsored by}

Natural History Museum Library, London

\section{Copyright \& Reuse}

Copyright Status: Public domain. The BHL considers that this work is no longer under copyright protection.

This document was created from content at the Biodiversity Heritage Library, the world's largest open access digital library for biodiversity literature and archives. Visit BHL at https://www.biodiversitylibrary.org. 